\title{
Nhận thức và thực hành về bệnh cao huyết áp của người cao tuổi tại xã Nhị Bình, huyện Hóc Môn
}

\section{Perception and practice of hypertension among the elderly at Nhi Binh Commune, Hoc Mon District}

\author{
Lê Thị Ngọc Phúc ${ }^{1 *}$ \\ ${ }^{1}$ Trường Đại học Khoa học Xã hội và Nhân văn, Việt Nam \\ *Tác giả liên hệ, Email: phucle@hcmussh.edu.vn
}

\section{THÔNG TIN}

DOI: 10.46223/HCMCOUJS. soci.vi.16.1.1396.2021

Ngày nhận: 12/03/2021

Ngày nhận lại: 24/03/2021

Duyệt đăng: 01/04/2021

\section{Tù khóa:}

nhận thức về cao huyết áp, người cao tuổi, nghiên cứu định tính, Hóc Môn

\section{Keywords:}

perception of hypertension, the elderly, qualitative research, Hoc Mon

\section{TÓM TẮT}




\section{1. Đặt vấn đề}

Tăng huyết áp (huyết áp cao) là một trong những tình trạng sức khỏe mãn tính phổ biến nhất trên thế giới và là yếu tố nguy cơ hàng đầu gây tử vong và gánh nặng bệnh tật (Ezzati, Lopez, Rodgers, Vander, \& Muray, 2002). Bệnh cao huyết áp là một trong những vấn đề sức khỏe mang tính toàn cầu hiện nay bởi vì tỷ lệ mắc bệnh ngày càng gia tăng, từ $26,4 \%$ dân số toàn thế giới năm 2000 dự tính sẽ tăng lên 29,2\% vào năm 2025 (Dao, 2007). Cao huyết áp là nguyên nhân dẫn đến bệnh tim mạch, tăng tỷ lệ mắc bệnh nhồi máu cơ tim, đột quỵ, suy tim và bệnh động mạch ngoại biên cũng như là nguyên nhân gây tàn phế và tử vong hàng đầu ở các nước đang phát triển nói riêng và toàn cầu nói chung (Dao, 2007; WHO, 2011). Tính đến năm 2015, có khoảng 422,7 triệu trường hợp mắc bệnh tim mạch trên toàn cầu và với tỷ lệ tử vong là 17,92 triệu mỗi năm. Bệnh tim mạch chiếm một phần ba số ca tử vong thế giới (Hội Tim mạch học Việt Nam, 2014; Trung tâm Nghiên cứu Chính sách và Phòng chống Chấn thương, 2016; WHO, 2011). Tuy nhiên, tình trạng này có thể phòng ngừa để giảm những ảnh hưởng đến sức khỏe của cá nhân cũng như gánh nặng bệnh tật và chi phí y tế của cộng đồng. Điều trị tăng huyết áp có thể giảm $40 \%$ nguy cơ tai biến mạch máu não và $15 \%$ nguy cơ nhồi máu cơ tim (Rahman et al., 2008; WHO, 2011).

Tại Việt Nam, cao huyết áp đã được xác định là một trong mười nguyên nhân hàng đầu gây bệnh tật và tử vong ở bệnh viện. Tuy nhiên, dữ liệu dựa trên dân số về cao huyết áp ở quy mô lớn vẫn chưa được cập nhật. Thực trạng hiện nay tỉ lệ người mắc bệnh cao huyết áp đang ngày càng gia tăng, từ $1 \%$ năm 1960 lên đến $11,7 \%$ năm 1992 và đến 47,3\% ở người từ 25 tuổi trở lên (Hội Tim mạch học Việt Nam, 2014; Trung tâm Nghiên cứu Chính sách và Phòng chống Chấn thương, 2016).

Bệnh cao huyết áp là căn bệnh có thể được điều chỉnh và có hướng dẫn điều trị rõ ràng để giúp bác sĩ và bệnh nhân của họ kiểm soát tăng huyết áp. Cụ thể như, để kiểm soát cao huyết áp tốt thì người bệnh cần điều chỉnh nhiều thói quen sống như giảm lượng muối trong khẩu phần ăn, tăng cường vận động, không uống nhiều rượu, giảm căng thẳng, và sử dụng các loại thuốc hạ huyết áp hiệu quả. Mặc dù, các khuyến cáo này và các liệu pháp hiện có được truyền thông rộng rãi nhưng tỷ lệ bệnh nhân không kiểm soát được huyết áp vẫn tương đối cao (Correa, Rochlani, Khan, \& Aronow, 2018; Whelton, He, \& Muntner, 2004). Số liệu thống kê cho thấy, tỷ lệ bệnh nhân Châu Á không kiểm soát được huyết áp thậm chí còn cao hơn 70\% (Aekplakorn et al., 2012; Lee et al., 2010; Rampal, Rampal, Azha, \& Rahman, 2008; Wu et al., 2009). Như vậy sự hiểu biết toàn diện về kiến thức, thái độ và nhận thức của người bệnh, cộng đồng và các bác sĩ về tăng huyết áp sẽ giúp chúng ta xác định các rào cản và quá trình kiểm soát tăng huyết áp hiệu quả nhằm phát triển những chương trình cải thiện nhận thức, điều trị và kiểm soát tăng huyết áp.

Trong các nghiên cứu ở trên thế giới cũng như Việt Nam, mối quan hệ giữa bệnh cao huyết áp và các bệnh tật khác luôn được quan tâm tìm hiểu. Chẳng hạn như, bệnh tăng huyết áp có thể dẫn đến các bệnh lý về thận, nội tiết, mạch máu, tim (Egan, Lackland, \& Cutler, 2003; Taylor \& Ward, 2003). Từ đó, kết quả cho thấy sự ảnh hưởng kép của bệnh tật thể hiện ở điểm vừa gây ra sự suy giảm về sức khỏe và tăng gánh nặng tài chính (Doan, 2015) bởi vì hiện nay các dịch vụ y tế tiết kiệm chi phí để kiểm soát các bệnh mãn tính mới nổi này ở các nước đang phát triển, trong đó có Việt Nam thì có giới hạn và thường phải chia sẻ với gánh nặng đồng thời của các bệnh truyền nhiễm.

Ngoài ra, các nghiên cứu trước đây còn tập trung mô tả tổng quát về tình hình cao huyết áp ở người già Việt Nam. Trong đó, kết quả trình bày tỷ lệ tăng huyết áp ở nam giới cao đáng kể và tỷ lệ này ở môi trường nông thôn thì thấp hơn môi trường đô thị (Meiqari, Essink, Wright, \& Scheele, 2019). Đồng thời, kết quả của một số công trình nghiên cứu khác về người cao tuổi và 
cao huyết áp tại Việt Nam cũng xác định những yếu tố nguy cơ chính gây tăng huyết áp ở người cao tuổi như thói quen ăn uống, đặc biệt là ăn mặn và hành vi liên quan đến sức khỏe như uống rượu (Ho, Nguyen, Vo, Derese, \& Devroey, 2018; Wakayabashi, 2013).

Như vậy, các nghiên cứu trong và ngoài nước đã và đang tập trung đến bệnh cao huyết áp ở người già nhằm góp phần chăm sóc sức khỏe cho đối tượng này tốt hơn và kéo dài tuổi thọ. Tuy nhiên, đa phần các nghiên cứu tập trung về tình hình sức khỏe của người già, các yếu tố nguy cơ dẫn đến bệnh cao huyết áp, mối liên quan giữa cao huyết áp và những căn bệnh khác và cách phòng và điều trị bệnh cao huyết áp bằng dược liệu. Riêng đối với những nghiên cứu tìm hiểu về quan điểm bệnh tật, cách thức chăm sóc bệnh và những nhân tố tác động đến nhận thức và hành vi của người già, một trong những nhóm có tỷ lệ tăng huyết áp cao và thường mắc nhiều bệnh tật cùng một lúc, vẫn chưa được nghiên cứu nhiều.

Từ đó, bài viết tập trung tìm hiểu những nhận thức của NCT về bệnh cao huyết áp và các yếu tố tác động đến những nhận thức này nhằm cung cấp thêm dữ liệu lý giải vì sao nhiều chương trình truyền thông sức khỏe về cao huyết áp được thực hiện rộng khắp và liên tục nhưng tỷ lệ NCT không kiểm soát được huyết áp vẫn cao. Đồng thời, bài viết cũng cung cấp cái nhìn khác biệt về bệnh cao huyết áp giữa NCT và bác sĩ. Từ đó, đề xuất một vài giải pháp cho bác sĩ trong quá trình tư vấn, thăm khám và điều trị bệnh cao huyết áp cho NCT.

\section{Phương pháp nghiên cứu}

Nghiên cứu được thiết kế theo hướng định tính. Các chủ đề nghiên cứu trong đi sâu vào việc tìm hiểu nhận thức của NCT về bệnh cao huyết áp và các yếu tố tác động đến quá trình nhận thức này. Toàn bộ dữ liệu được thu thập vào năm 2020 tại xã Nhị Bình, huyện Hóc Môn ${ }^{1}$. Các cuộc phỏng vấn định tính được thực hiện tại nhà của NCT. Tổng cộng $28 \mathrm{NCT}$ được chẩn đoán bệnh cao huyết áp và 02 bác sĩ đang công tác tại Trạm Y tế và phòng khám tư nhân đã tham gia nghiên cứu. Trong đó, $20 \mathrm{NCT}$ tham gia vào phỏng vấn sâu và 08 người tham gia vào thảo luận nhóm. Các cuộc phỏng vấn định tính (kéo dài khoảng 40 phút mỗi cuộc). Trong quá trình phỏng vấn, nhóm nghiên cứu đều nhận được sự cho phép của NCT tiến hành ghi âm buổi trao đổi. Đồng thời, nhóm nghiên cứu cũng thực hành ghi chép thực địa. Toàn bộ thông tin được cung cấp bởi các thông tín viên chỉ phục vụ cho công tác nghiên cứu và xuất bản. Những thông tin cá nhân đều được mã hóa danh tính.

Ngoài ra, đề tài còn tiến hành 02 cuộc thảo luận nhóm tập trung bao gồm 4 NCT cho mỗi cuộc, trong đó 01 cuộc gồm những NCT là nữ và 01 cuộc gồm những NCT là nam. Các cuộc trò chuyện trực tiếp này kéo dài từ 60 đến 90 phút tại văn phòng ấp hoặc ủy ban nhân dân xã Nhị Bình. Trong các cuộc thảo luận, chủ đề tập trung tìm hiểu sự hiểu biết, thái độ và thực hành của các thông tín viên trong việc kiểm soát huyết áp.

Các mẫu nghiên cứu được chọn lựa theo tiêu chí (1) các thông tín viên có độ tuổi từ 60 tuổi trở lên, đang sinh sống tại xã Nhị Bình, (2) các thông tín viên tự báo cáo tình trạng cao huyết áp có chỉ định điều trị của các bác sĩ trong vòng 24 tháng, và (3) các thông tín viên có hoặc không có bảo hiểm y tế đều thuộc đối tượng nghiên cứu. Dữ liệu sau khi thu thập được tiến hành xử lý và phân tích theo nhóm chủ đề.

Nghiên cứu được tiến hành tại xã Nhị Bình, huyện Hóc Môn. Đây là xã nằm về phía Đông, Bắc giáp với thị xã Thuận An, tỉnh Bình Dương được bao bọc bởi sông Sài Gòn, phía Nam giáp phường Thạnh Xuân, Quận 12, phía Tây giáp với xã Đông Thạnh huyện Hóc Môn

\footnotetext{
${ }^{1}$ Trích từ bộ dữ liệu đề tài cấp cơ sở 2020 "Nhận thức và Thực hành chăm sóc sức khỏe của người già với bệnh cao huyết áp tại xã Nhị Bình, huyện Hóc Môn, Thành phố Hồ Chí Minh”, mã số đề tài T2020-06
} 
cách trung tâm huyện khoảng $12 \mathrm{~km}$. Diện tích tự nhiên 844,45 ha, trong đó diện tích đất nông nghiệp 606,66 ha chiếm tỷ lệ $71,09 \%$ diện tích của xã. Địa giới hành chính phân thành 04 ấp, 51 tổ nhân dân.

Tình hình kinh tế - xã hội tiếp tục phát triển, đời sống vật chất, tinh thần của nhân dân từng bước cải thiện, trong đó có $\mathrm{NCT}$, an ninh chính trị, trật tự an toàn xã hội được giữ vững. Theo báo cáo kết quả thực hiện chương trình hành động quốc gia về NCT giai đoạn 2013 2020, trên địa bàn xã có 2779 hộ với 14.728 nhân khẩu. Trong đó số hộ có NCT là 1089 hộ, số NCT từ 60 tuổi trở lên là 1694 người chiếm tỷ lệ $11,50 \%$ dân số. NCT từ $60-79$ tuổi là 1.483 người, từ 80 - 101 tuổi là 209 người, 100 tuổi là 01 người, trên 100 tuổi là 01 người. Có 1030 người tham gia hội viên Hội NCT; Hộ nghèo đầu năm 2020 còn 18 hộ; Hộ cận nghèo còn 48 hộ. Trong đó có 03 hộ NCT thuộc hộ nghèo.

\section{Kết quả nghiên cứu}

\section{1. Đặc điểm thông tín viên}

Hầu hết NCT tham gia vào nghiên cứu này có độ tuổi từ 60 đến 70 . Trong đó, số lượng NCT là nữ gồm 17 người và NCT là nam gồm 11 người. Trình độ học vấn của NCT tập trung chủ yếu ở cấp 02 , chỉ có $04 \mathrm{NCT}$ đạt trình độ học vấn cấp 03 và $02 \mathrm{NCT}$ hoàn thành trình độ Đại học. Riêng đối với thời gian được bác sĩ chẩn đoán cao huyết áp từ 03 năm đến 05 năm là 05 người, từ 05 năm trở lên đến dưới 8 năm là 13 người và có 02 người được chẩn đoán bệnh từ 8 năm trở lên (xem Bảng 1).

Đối với các thông tín viên là bác sĩ gồm 01 người đang công tác tại Trạm Y tế, 01 người công tác tại phòng khám tư nhân trên địa bàn xã nơi NCT thường thăm khám khi không đến bệnh viện.

\section{Bảng 1}

Đặc điểm thông tín viên

\begin{tabular}{|l|c|}
\hline \multicolumn{1}{|c|}{ Giới tính } & $\mathbf{2 8}$ \\
\hline Nam & 11 \\
\hline Nữ & 17 \\
\hline Trình độ học vấn & 6 \\
\hline Cấp 1 & 16 \\
\hline Cấp 2 & 4 \\
\hline Cấp 3 & 2 \\
\hline Cao đẳng/Đại học & 8 \\
\hline Thời gian được chẩn đoán cao huyết áp & 5 \\
\hline Từ 2 năm đến dưới 3 năm & 13 \\
\hline Từ 3 năm đến 5 năm & 2 \\
\hline Từ 5 năm trở lên đến dưới 8 năm & \\
\hline Trên 8 năm & \\
\hline
\end{tabular}

Nguồn: Dữ liệu thu thập từ tháng 08 đến tháng 10/2020 


\subsection{Nhận thức của NCT về bệnh cao huyết áp}

\subsubsection{Nhận thức về múc độ nghiêm trọng của bệnh cao huyết áp đối với súc khỏe}

Toàn bộ NCT trong nghiên cứu này đều nhận thức cao huyết áp là căn bệnh "giết người" thầm lặng và không thể điều trị dứt điểm. Do đó, họ thường bày tỏ việc chấp nhận sống chung với bệnh này suốt đời. Đây là căn bệnh ảnh hưởng đến sinh hoạt hàng ngày của NCT. NCT không thể làm bất kỳ công việc gì, thậm chí là tự chăm sóc cá nhân khi huyết áp tăng.

Các NCT cũng nhận ra rằng cao huyết áp có thể dẫn đến những hậu quả nặng nề như đột quy, tê liệt do đột quỵ và đau tim. Như chia sẻ của nhóm NCT nữ tham gia thảo luận nhóm.

"Người ta hay nói bệnh này là kẻ giết người thầm lặng, mình không có biết trước được khi nào nó đến... Tụi cô thấy căn bệnh này không thể chữa khỏi được đâu, phải sống chung với nó suốt cuộc đời cho tới chết thì thôi." (Nũu, 70 tuổi, chẩn đoán điều trị 05 năm, ngày thảo luận nhóm 09.08.2020).

Hoặc theo chia sẻ của NCT với 08 năm kiểm soát huyết áp không tăng cao cho biết:

"Lớn tuổi như chú đây thì không chỉ mắc 1 bệnh mà nhiều bệnh cùng lúc. Cái vụ cao huyết áp này thấy nhẹ nhưng không phải nhẹ đâu, khi mà huyết áp lên cao chóng mặt mình đi không vững té ngã gãy tay chân hoặc là có khi đột quy, mà giờ người ta chết vì đột quỵ nhiều lắm.” (Nam, 64 tuổi, chẩn đoán điều trị 03 năm, ngày thảo luận nhóm 17.08.2020).

Mặc dù hầu hết NCT thừa nhận nguy cơ đột quỵ cao cũng như các biến chứng khác, nhưng một vài NCT vẫn đánh giá cao huyết áp thì ít nghiêm trọng hơn các bệnh mà NCT thường mắc phải như tim mạch, tiểu đường và xương khớp. Điển hình như chia sẻ của hơn $2 / 3 \mathrm{NCT}$ cho rằng:

“Cao huyết áp không nghiêm trọng vì mình có thể kiểm soát được nó chứ như bệnh tim lên cơn đau đột ngột, nhồi máu nữa là chỉ có chết...Bệnh tiểu đường nó kiểm soát giảm đường, hạn chế ăn cơm chứ khi mà giai đoạn cuối lỡ loét phải cắt bỏ các phần trên cơ thể cũng không còn lành lặn gì...Còn viêm khớp là thôi không đi đứng gì được vì nó nhức chịu không nổi." (Nam, 68 tuổi, chẩn đoán điều trị 02 năm, ngày thảo luận nhóm 16.08.2020).

\subsubsection{Nhận thức về dấu hiệu bệnh cao huyết áp}

Theo kết quả phỏng vấn và thảo luận nhóm, các NCT đều cho rằng họ khó nhận diện được các triệu chứng bệnh lý trước khi họ được chẩn đoán bởi bác sĩ. Họ chỉ phát hiện bệnh khi thăm khám các bệnh khác hoặc khi huyết áp của họ tăng cao nghiêm trọng. Chính vì vậy, một vài NCT chia sẻ họ khó chấp nhận sự thật huyết áp của họ tăng cao.

Tuy nhiên sau khi được chẩn đoán cao huyết áp hoặc từ những câu chuyện trong gia đình và trải nghiệm bản thân, NCT đưa ra các dấu hiệu khi huyết áp chuẩn bị tăng cao cần uống thuốc để kiểm soát. Những dấu hiệu đó bao gồm: mặt đỏ bừng như vừa đi ngoài nắng gắt, mặt cảm giác nặng và hơi sưng. Giai đoạn nặng hơn sẽ nhức đầu chóng mặt, triệu chứng giống như rối loạn tiền đình. Như chia sẻ của một NCT nữ được chẩn đoán cao huyết áp 02 năm:

"Ban đầu, cô không biết cô bị cao huyết áp vì thấy mình vẫn khỏe mạnh bình thường, nhiều người nói cô sắp 70 mà nhìn vẫn khỏe... Hình như hồi 2018 cô tự nhiên đang dọn dẹp nhà cửa thấy chóng mặt quá đi nằm và uống thuốc đau đầu Panadol gì đó. Rồi thấy nó bớt, nhưng vài ngày sau cô lại bị nặng hơn, mấy đứa nhỏ nó chở cô ra phòng khám gần đây thì bác sĩ nói cô bị cao huyết áp, rồi cho uống thuốc hạ." (Nũu, 62 tuổi, chẩn đoán điều trị 02 năm, ngày phỏng vấn 24.08.2020). 


\subsubsection{Nhận thức về nguyên nhân dẫn đến cao huyết áp}

Theo các NCT, nguyên nhân dẫn đến cao huyết áp là do ăn uống, lao động vất vả và lo âu. Họ chia sẻ rằng thói quen ăn muối hoặc những thực phẩm ngày nay nguồn gốc không rõ ràng là nguyên nhân chủ yếu dẫn đến căn bệnh. Trước đây, thực phẩm họ sử dụng thường là thực phẩm sạch bởi vì thuốc trừ sâu, phân bón, thuốc kích thích tăng trưởng không được sử dụng nhiều nên họ hoàn toàn an tâm. Tuy nhiên, thực phẩm ngày nay chứa nhiều chất độc hại cho cơ thể. Theo chia sẻ, các chất này thấm vào cơ thể ngày một ít đến một ngày nào đó thì sinh ra đủ loại bệnh tật, trong đó có bệnh cao huyết áp.

Ngoài ra, NCT thường lo nghĩ khá nhiều về gia đình, con cái nên việc kiểm soát huyết áp cũng không hiệu quả.

\subsubsection{Nhận thức về tác dụng phụ của thuốc}

Những NCT có thời gian chẩn đoán cao huyết áp từ 2-3 năm cho biết ban đầu họ không thể nhớ được nên uống thuốc trước hay sau bữa ăn bởi vì họ phải uống nhiều loại thuốc cho nhiều bệnh khác nhau cùng một lúc. Chính vì vậy, nhiều NCT cảm thấy đói bụng hoặc mệt mỏi khi uống thuốc trước bữa ăn.

"Nhiều khi thuốc của cô uống sau bữa ăn nhưng cô hay uống trước khi ăn nên cô thấy bụng mình nó cồn cào, khó chịu." (Nũu, 72 tuổi, chẩn đoán điều trị 05 năm, ngày phỏng vấn 10.09.2020).

Hoặc trong cuộc thảo luận nhóm dành cho NCT nũ̃, một NCT đã chia sẻ cảm giác lo lắng về tác dụng phụ của thuốc. Thông tín viên này cho rằng nếu sử dụng thuốc không đúng cách sẽ ảnh hưởng đến trí nhớ sau này.

"Cô không có uống thường xuyên hàng ngày mà chỉ khi nào cô thấy thật sự mệt cô mới uống, tại cô nghe nói uống thuốc này lâu dài sẽ làm mất trí nhớ:" (Nưu, 60 tuổi, chẩn đoán điều trị 04 năm, ngày thảo luận nhóm 09.08.2020).

\subsection{Thục hành của NCT về việc kiểm soát cao huyết áp}

\subsubsection{Sư dụng thuốc}

Hầu hết NCT đều tuân thủ theo hướng dẫn của bác sĩ phải uống thuốc đều đặn hàng ngày. Họ bày tỏ sự lo lắng nếu họ không dùng thuốc hàng ngày thì tình trạng bệnh sẽ nặng hơn và ảnh hưởng đến gia đình, con cháu phải chăm sóc.

“Tụi chú là uống thuốc hàng ngày. Không bao giờ quên”. (Nam, 68 tuổi, chẩn đoán điều trị 02 năm, ngày thảo luận nhóm 16.08.2020).

"Cô giờ không chỉ uống thuốc hàng ngày mà cho dù cô đi đâu cô cũng đếm thuốc mang theo đủ” (Nũu, 64 tuổi, chẩn đoán điều trị 04 năm, ngày thảo luận nhóm 09.08.2020).

Tuy nhiên, có $04 \mathrm{NCT}$ chia sẻ rằng có thời gian họ ngưng sử dụng thuốc. Sau đó, tình trạng sức khỏe của những NCT này kém hơn nên họ quyết định sử dụng lại thuốc. Lý do họ ngưng sử dụng thuốc vì họ cảm nhận sức khỏe tốt hơn vào thời điểm đó cũng như việc uống thuốc đều đặn hàng ngày khiến họ chán, hoặc họ cho rằng thuốc bác sĩ kê toa không phù hợp với cơ thể của họ.

“Cô cũng từng ngừng dùng thuốc trước đây 1 năm. Cô thấy lúc đó cô khỏe hơn với lại uống hoài cô thấy thuốc là cô ngán. Nhưng hồi đầu năm nay, cô bị trở lại, huyết áp lên 16 , cô sợ quá nên cô đi khám và đang uống thuốc lại. Thuốc đợt này thấy khác với đợt trước." (Nữ, 65 tuổi, chẩn đoán điều trị 03 năm, ngày phỏng vấn 12.09.2020). 
“Đợt 2016 chú được chẩn đoán cao huyết áp ở bệnh viện Hóc Môn, bác sĩ cũng cho thuốc về uống mà chú thấy không có bớt nhiều nên lúc hết thuốc chú không đi tái khám lại. Đâu khoảng 2-3 tháng sau, chú bị bệnh trở lại, chú mới kêu đứa con đi ra tiệm thuốc tây gần ủy ban mua cho chú. Tại mọi người ở xã này nói tiệm thuốc đó có nhiều loại thuốc hay mà bệnh viện không có." (Nam, 66 tuổi, chẩn đoán điều trị 04 năm, ngày phỏng vấn 19.09.2020).

\subsection{2. Điều chỉnh thói quen sinh hoạt hàng ngày}

Theo chia sẻ của NCT, để kiểm soát huyết áp cũng như phòng ngừa thì họ cần giảm lượng muối trong khẩu phần ăn hàng ngày, tăng cường tập thể dục và uống thuốc đều đặn. Tuy nhiên việc duy trì thói quen giảm lượng muối khó thực hiện với một số NCT ở chung với gia đình.

“Giờ cô lớn tuổi rồi không làm gì được, nhiều khi nấu ăn cũng bữa được bữa mất nên giờ con dâu cô nấu. Mà nó nấu thế nào mình ăn như vậy chứ mình đâu có thể góp ý gì nhiều, nói nhiều nó không thích rồi buồn vui trong gia đình." (Nũu, 62 tuổi, chẩn đoán điều trị 02 năm, ngày phỏng vấn 12.09.2020).

Liên quan đến việc tập thể dục, NCT chia sẻ rằng họ không có tập thể dục bài bản mà thông thường họ sẽ tự tập những động tác nhẹ trong khoảng thời gian từ 15 đến 30 phút như đi bộ, giơ tay giơ chân, hoặc dọn dẹp nhà vào buổi sáng. Lý do họ không tập thể dục đúng bài bản vì họ ít xem tivi hoặc cũng không có tham gia hội dưỡng sinh ở xã. Họ cho rằng họ không có đủ thời gian để tập đúng các bước trên truyền hình hướng dẫn.

"Một số NCT tham gia hội dưỡng sinh buổi sáng cũng tốt lắm, họ chỉ cho mình cách hít thở rồi tập kiểu này kiểu kia. Còn như mấy cô đây, mở mắt ra là thấy công việc làm không nghỉ tay. Bữa nào siêng lắm thì cô đứng quơ tay quơ chân lên xuống 5-10 phút gì đó. Còn không là quét cái nhà cái sân từ đằng trước ra đằng sau là coi như tập thể dục rồi đó." (Nũu, 64 tuổi, chẩn đoán điều trị 04 năm, ngày thảo luận nhóm 09.08.2020).

\subsubsection{Nhận thức về việc kiểm soát huyết áp giũa NCT và bác sĩ}

Kết quả nghiên cứu cũng cho thấy một vài điểm khác biệt giữa nhận thức của NCT và bác sĩ trong việc kiểm soát huyết áp. Trong khi các bác sĩ cho rằng, yếu tố quan trọng để kiểm soát huyết áp ở mức ổn định là cải thiện thói quen sinh hoạt hàng ngày của NCT. Tuy nhiên, NCT lại cho rằng thuốc đóng vai trò quan trọng trong việc kiểm soát huyết áp, nếu họ không dùng thuốc đều đặn thì tình trạng bệnh sẽ nặng hơn và có thể dẫn đến nhiều căn bệnh khác.

“Các bác đến đây khám, trạm luôn tư vấn uống thuốc thường xuyên và kiểm soát chế độ ăn uống” (Bác sĩ tại Trạm Y tế).

Ngoài ra, các bác sĩ đánh giá cao việc tuân thủ thăm khám đều đặn để theo dõi huyết áp mục tiêu và điều chỉnh thuốc khi cần thiết là cách thức kiểm soát huyết áp thành công và hiệu quả. Tuy nhiên, một vài NCT cho rằng tuân thủ sử dụng thuốc theo hướng dẫn chỉ là một phần, quan trọng là thuốc uống có phù hợp với cơ thể và không có bất kỳ tác dụng phụ thì mới được xem là kiểm soát huyết áp thành công.

"Nhiều bác đến mình khám nhiều khi mình cũng tư vấn cụ thể, dặn dò nhưng mà các bác ít tuân thủ theo. Tháng đi tháng không, thói quen của các bác là khi nào nặng mới tìm đến bác sĩ. Mình cũng phải thông cảm vì nhiều khi các bác lớn tuổi hay quên rồi con cháu bận việc không chở đi khám” (Bác sĩ tại phòng khám).

Mặt khác, một vài NCT bày tỏ mong muốn các bác sĩ chủ động trò chuyện với họ hơn khi thăm khám. Bởi vì họ cảm thấy khám tư vấn quá ngắn gọn, mang tính trao đổi một chiều. 
Thông thường, bác sĩ báo kết quả tổng quát và nhắc nhở dùng thuốc, nhưng họ thường không cung cấp cho bệnh nhân thông tin hữu ích cụ thể. Nếu các bác sĩ đưa ra lời khuyên cải thiện thói quen sinh hoạt. Các bác sĩ thường không thông cảm với hoàn cảnh của họ cũng như những mối quan tâm, những khó khăn của họ trong việc kiểm soát huyết áp của họ.

"Nhiều khi lên bệnh viện chờ đã đời vô khám, bác sĩ cho toa rồi dặn ăn uống này nọ rồi xong. Mình không có thời gian hỏi thêm thông tin gì nhiều hết. Nên nhiều khi mình thấy đi ra tiệm thuốc tây mua cho lẹ không phải chờ đợi" (Nũu, 63 tuổi, chẩn đoán cao huyết áp 02 năm).

\subsection{Các yếu tố tác động đến nhận thức của NCT về bệnh cao huyết áp}

\subsubsection{Truyển thông}

Theo chia sẻ của NCT trong nghiên cứu này, những thông tin liên quan đến bệnh cao huyết áp họ nhận được từ bác sĩ hoặc tiệm thuốc tây. Một số NCT khác có tham gia hội/đoàn thể ở địa phương cũng nhận được thông tin liên quan khi các hội/đoàn thể này tổ chức sinh hoạt. Bên cạnh đó, theo chia sẻ của Trạm Y tế thỉnh thoảng trạm cũng có tuyên truyền về bệnh cao huyết áp bằng tờ rơi tại Trạm, biểu ngữ hoặc xe phát thanh lưu động vào tháng 10 hàng năm vì đây là tháng hành động vì người cao tuổi. Chính những thông tin và hình thức truyền thông này đã ảnh hưởng đến nhận thức và kiểm soát huyết áp cao hiệu quả của NCT.

Một vài NCT còn cho biết rằng, hình thức truyền thông trên tivi trong chương trình Bác sĩ gia đình của Đài Truyền hình Vĩnh Long cũng khá hay nhưng họ thường không có thời gian xem cũng như không nhớ lịch phát sóng định kỳ. NCT tin rằng những thông tin phát trên truyền hình và từ bác sĩ thì hiệu quả và chính xác cao hơn những thông tin trên mạng xã hội. Bởi vì mạng xã hội nhiều thông tin, họ không thể kiểm chứng thật giả. Do đó, họ thường tìm đến tiệm thuốc tây, Trạm Y tế hoặc bệnh viện để mua thuốc mặc dù có nhiều thông tin hướng dẫn sử dụng cây cỏ nhưng họ không thực hành theo.

\subsubsection{Gia dinh}

Kết quả nghiên cứu cũng cho thấy một vài NCT không thực hiện thăm khám đều đặn theo hướng dẫn của bác sĩ bởi vì người thân không thu xếp được công việc để đưa đến cơ sở y tế.

"Cô không biết đi xe máy nên toàn là mấy đứa con chở đi. Nhiều bữa đến lịch khám nhưng mà nó bận chưa xin nghỉ được nên cô cũng đi khám trễ một vài ngày. Vô bác sĩ có hỏi sao khám trễ thì nói là mình quên." (Nưu, 63 tuổi, chẩn đoán điều trị 02 năm, ngày phỏng vấn 19.09.2020).

Ngoài ra, nhiều NCT chia sẻ rằng họ đã phải thay đổi thói quen sinh hoạt hàng ngày trong ăn uống và tập thể dục buổi sáng bởi vì họ tiếp xúc hoặc chứng kiến những câu chuyện đột quỵ của người thân. Họ cho rằng cao huyết áp và đột quỵ có mối quan hệ với nhau. Theo họ, khi huyết áp lên cao họ sẽ có cảm giác chóng mặt, trong trường hợp không cẩn thận họ sẽ té ngã hoặc dẫn đến đột quỵ. Chính vì vậy, họ luôn thăm khám đều đặn theo lời hướng dẫn của bác sĩ, hạn chế ăn mặn, tập thể dục buổi sáng tại nhà hoặc tham gia vào câu lạc bộ dưỡng sinh.

"Nhà cô có người họ hàng chạc tuổi cao bị đột quy, cô nghe thấy mà sợ. Giờ người đó nói chuyện lấp bấp và bị méo mặt. Thời buổi này đột quỵ sao mà nhiều quá. Hôm trước cô nghe trên đài nói huyết áp với cái vụ đột quỵ có liên quan với nhau. Thành ra cô giờ bớt ăn mặn, chứ cô thích ăn mắm lắm. Sáng sáng bữa nào khỏe thì cô đi tập thể dục với mấy người trong xóm, còn không thì ở nhà cô cũng giơ tay giơ chân mấy cái cho nó giãn gân cốt.” (Nưu, 65 tuổi, chẩn đoán điều trị 05 năm, ngày phỏng vấn 20.09.2020). 


\subsubsection{Trải nghiệm cá nhân}

Đối với NCT có thời gian chẩn đoán cao huyết áp từ hai đến ba năm chia sẻ rằng thông tin về cao huyết áp họ cũng được nghe nhiều nhưng họ thường không để tâm đến. Chính vì vậy, họ không nhớ rõ những thông tin được cung cấp cho tới khi họ mắc phải căn bệnh này. Họ phải tìm hiểu nhiều hơn để cải thiện tình trạng sức khỏe vì họ không muốn trở thành gánh nặng cho gia đình.

Riêng nhóm NCT được chẩn đoán cao huyết áp từ 05 năm trở lên chia sẻ quá trình tuân thủ theo hướng dẫn của bác sĩ về bệnh cao huyết áp cũng thay đổi thói quen sinh hoạt hàng ngày của họ trở nên tốt hơn. Trước đây, bởi vì cuộc sống vất vả nên thời gian họ lao động rất nhiều, họ không có thời gian chăm sóc bản thân, chẳng hạn như tham gia hội dưỡng sinh. Song song đó, việc họ chủ động tham gia Hội Người Cao tuổi và sinh hoạt đều đặn, họ cũng cảm thấy vui vẻ hơn. Bởi vì Hội thường tổ chức các buổi thông tin về những căn bệnh NCT gặp phải, cách phòng ngừa và làm thế nào để có cuộc sống tinh thần thoải mái.

Đối với một số NCT đã có thời gian ngưng sử dụng thuốc để kiểm soát huyết áp cũng cho biết những ảnh hưởng sức khỏe và cuộc sống khi không tuân thủ theo hướng dẫn của bác sĩ.

Kết quả nghiên cứu cũng cho thấy một vài điểm khác biệt giữa nhận thức của NCT và bác sĩ trong việc kiểm soát huyết áp. Sự khác biệt này cũng tác động phần nào đến nhận thức và thực hành của NCT về kiểm soát tăng huyết áp. Trong khi các bác sĩ cho rằng, yếu tố quan trọng để kiểm soát huyết áp ở mức ổn định là cải thiện thói quen sinh hoạt hàng ngày của NCT. Tuy nhiên, NCT lại cho rằng thuốc đóng vai trò quan trọng trong việc kiểm soát huyết áp, nếu họ không dùng thuốc đều đặn thì tình trạng bệnh sẽ nặng hơn và có thể dẫn đến nhiều căn bệnh khác.

"Các bác đến đây khám, trạm luôn tư vấn uống thuốc thường xuyên và kiểm soát chế độ ăn uống” (Bác sĩ tại Trạm Y tế).

Ngoài ra, các bác sĩ đánh giá cao việc tuân thủ thăm khám đều đặn để theo dõi huyết áp mục tiêu và điều chỉnh thuốc khi cần thiết là cách thức kiểm soát huyết áp thành công và hiệu quả. Tuy nhiên, một vài $\mathrm{NCT}$ cho rằng tuân thủ sử dụng thuốc theo hướng dẫn chỉ là một phần, quan trọng là thuốc uống có phù hợp với cơ thể và không có bất kỳ tác dụng phụ thì mới được xem là kiểm soát huyết áp thành công.

"Nhiều bác đến mình khám nhiều khi mình cũng tư vấn cụ thể, dặn dò nhưng mà các bác ít tuân thủ theo. Tháng đi tháng không, thói quen của các bác là khi nào nặng mới tìm đến bác sĩ. Mình cũng phải thông cảm vì nhiều khi các bác lớn tuổi hay quên rồi con cháu bận việc không chở đi khám" (Bác sĩ tại phòng khám).

Mặt khác, một vài NCT bày tỏ mong muốn các bác sĩ chủ động trò chuyện với họ hơn khi thăm khám. Bởi vì họ cảm thấy khám tư vấn quá ngắn gọn, mang tính trao đổi một chiều. Thông thường, bác sĩ báo kết quả tổng quát và nhắc nhở dùng thuốc, nhưng họ thường không cung cấp cho bệnh nhân thông tin hữu ích cụ thể. Nếu các bác sĩ đưa ra lời khuyên cải thiện thói quen sinh hoạt. Các bác sĩ thường không thông cảm với hoàn cảnh của họ cũng như những mối quan tâm, những khó khăn của họ trong việc kiểm soát huyết áp của họ.

"Nhiều khi lên bệnh viện chờ đã đời vô khám, bác sĩ cho toa rồi dặn ăn uống này nọ rồi xong. Mình không có thời gian hỏi thêm thông tin gì nhiều hết. Nên nhiều khi mình thấy đi ra tiệm thuốc tây mua cho lẹ không phải chờ đợi” (Nũu, 63 tuổi, chẩn đoán điều trị 02 năm, ngày phỏng vấn 19.09.2020). 


\section{Kết luận}

Kết quả nghiên cứu này cũng tương tự một vài nghiên cứu trước đây về nhận thức về bệnh cao huyết áp cũng như nguyên nhân dẫn đến căn bệnh dưới góc nhìn của bệnh nhân (Puveearasan \& Pankaj, 2018). Tuy nhiên, nghiên cứu này tập trung chủ yếu ở NCT, nhóm người thường mắc phải nhiều bệnh tật cùng lúc. Ngoài ra, nghiên cứu này còn tìm hiểu những yếu tố tác động đến nhận thức của NCT về bệnh cao huyết áp.

Điểm mạnh chính trong nghiên cứu của chúng tôi là thiết kế định tính để có thể tìm hiểu sâu hơn về những nhận thức của NCT về bệnh cao huyếp áp. Từ đó, kết quả cho thấy nhận thức của bệnh nhân thường rất khác với nhận thức của bác sĩ (Trung tâm Nghiên cứu Chính sách và Phòng chống Chấn thương, 2016). Vì vậy, sự khác biệt trong nhận thức của bệnh nhân và bác sĩ sẽ hỗ trợ cung cấp thông tin chi tiết hơn cho các bác sĩ trong quá trình giúp các bệnh nhân kiểm soát tăng huyết áp. Tuy nhiên, những thông tín viên sẵn sàng tham gia phỏng vấn và các nhóm tập trung có thể không phải là đại diện cho dân số chung.

Bên cạnh đó, các phát hiện từ nghiên cứu này chủ yếu tiến hành ở khu vực nông thôn và chỉ bao gồm những thông tín viên không cố ý ngừng dùng thuốc tăng huyết áp. Mặc dù, sự tuân thủ với thuốc không được đo lường trong nghiên cứu này và có thể những bệnh nhân sẵn sàng tham gia có thể không thừa nhận liệu họ có cố ý ngừng dùng thuốc hay không. Chính vì vậy, các nghiên cứu tiếp có thể tiến hành ở khu vực đô thị để so sánh liệu rằng có sự khác biệt trong nhận thức của NCT ở khu vực nông thôn và khu vực thành thị về bệnh cao huyết áp hay không. Ngoài ra, tiêu chí lựa chọn thông tín viên liên quan đến việc thực hành sử dụng thuốc kiểm soát huyết áp cũng cần được quan tâm bởi vì theo số liệu thống kê, tỷ lệ không tuân thủ thuốc điều trị tăng huyết áp ở bệnh nhân châu Á có thể cao tới 56\% (Hassan \& cộng sự, 2006).

Dựa theo kết quả nghiên cứu, NCT nhận thức rằng cao huyết áp là căn bệnh "giết người" thầm lặng và không thể điều trị dứt điểm. Mặc dù mức độ nghiêm trọng của căn bệnh này so với các nhóm bệnh thường gặp ở NCT như tim mạch, tiểu đường và xương khớp không cao, nhưng căn bệnh này có liên quan đến những căn bệnh khác và khiến cho sức khỏe của NCT yếu hơn. Nguyên nhân dẫn đến căn bệnh này là do ăn uống, lao động vất vả và căng thẳng tâm lý.

Ngoài ra, kết quả nghiên cứu còn phát hiện nhận thức của NCT và bác sĩ có vài điểm khác biệt về thực hành kiểm soát huyết áp. Mặc dù, NCT trong nghiên cứu đều tiếp nhận điều trị nhưng một số NCT vẫn không dùng thuốc thường xuyên, tự đổi loại thuốc khác không theo hướng dẫn của bác sĩ hoặc không chủ động thay đổi thói quen sinh hoạt hàng ngày. Do đó, để nâng cao hiệu quả thực hành kiểm soát tăng huyết áp của NCT, các bác sĩ nên bày tỏ sự thông cảm đối với những bệnh nhân lớn tuổi so với những bệnh nhân trẻ hơn vì những $\mathrm{NCT}$ có thể đang đối mặt với nhiều bệnh lý khác nhau, những chuyển biến trong tâm lý của NCT từ lo lắng căng thẳng đến chấp nhận và tạo động lực để tiếp tục điều trị cao huyết áp cũng bị tác động bởi nhiều yếu tố từ môi trường sống của NCT. Chính vì vậy, các bác sĩ nên dành một ít thời gian trong quá trình thăm khám để lắng nghe chia sẻ của NCT về những rào cản khiến NCT khó duy trì chế độ sinh hoạt đều đặn và dùng thuốc theo hướng dẫn. Từ đó, các bác sĩ và NCT cùng xây dựng một kế hoạch điều trị phù hợp cho từng đối tượng. Cách tiếp cận này có thể cải thiện sự tuân thủ của bệnh nhân NCT đối với lời khuyên của bác sĩ cao hơn những khuyến nghị chung chung từ bác sĩ. Bên cạnh đó, các bác sĩ cũng nên nhấn mạnh tầm quan trọng của việc thay đồi chế độ sinh hoạt hợp lý cho $\mathrm{NCT}$, giải thích cho $\mathrm{NCT}$ biết rằng việc điều chỉnh thói quen sinh hoạt có thể dẫn đến kết quả điều trị cao hơn. Ngoài ra, theo chia sẻ của NCT trong nghiên cứu, một số NCT gặp khó khăn trong việc giao tiếp với bác sĩ điều trị bởi vì thời gian làm việc và kỹ năng giao tiếp. Chính vì vậy, các bác sĩ cũng nên chủ động tham gia các khóa đào tạo về kỹ năng giao tiếp và tư vấn để cải thiện hiệu quả chăm sóc sức khỏe cho NCT. 
Những nhận thức về bệnh cao huyết áp và thực hành của NCT chịu sự ảnh hưởng của các chương trình truyền thông sức khỏe, gia đình và trải nghiệm bản thân. Trong đó, NCT đặt niềm tin vào các chương trình truyền thông sức khỏe được tổ chức trong các buổi sinh hoạt của hội/đoàn thể và tư vấn trực tiếp từ bác sĩ hơn là các chương trình truyền thông trên mạng xã hội bởi vì khả năng truy cập mạng xã hội của NCT còn hạn chế.

\section{LÒ̀I CẢM ON}

Nghiên cứu được tài trợ bởi Trường Đại học Khoa học Xã hội và Nhân văn, Đại học Quốc gia Thành phố Hồ Chí Minh trong khuôn khổ đề tài mã số T2020-06.

\section{Tài liệu tham khảo}

Aekplakorn, W., Sangthong, R., Kessomboon, P., Putwatana, P., Inthawong, R., Taneepanichskul, S.,... Chariyalertsak, S. (2012). Changes in prevalence, awareness, treatment and control of hypertension in Thai population, 2004-2009: Thai national health examination survey III-IV. Journal of Hypertension, 30(9), 1734-1742.

Correa, A., Rochlani, Y., Khan, M. H., \& Aronow, W. S. (2018). Pharmacological management of hypertension in the elderly and frail populations. Expert Review of Clinical Pharmacology, $11(8), 805-817$.

Dao, A. D. (2007). Tăng huyết áp thầm lặng như thế nào [How silent hypertension]. Tạp chí Tim mạch học Việt Nam, 47, 445-451.

Doan, H. T. T. (2015). Phân tích thực trạng sủ dụng thuốc trên bệnh nhân tăng huyết áp kèm đái tháo đưòng tại phòng khám ngoại trú bệnh viện Y hoc Cổ truyền - Bộ Công an [Analysis of the current situation of drug use in hypertensive patients with diabetes at the outpatient clinic of Traditional Medicine Hospital - Ministry of Public Security] (Master's thesis). Trường Đại học Dược Hà Nội, Hanoi, Vietnam.

Egan, B. M., Lackland, D. T., \& Cutler, N. E. (2003). Awareness, knowledge and attitudes of older Americans about high blood pressure: Implications for healthcare policy, education, and research. Archives of Internal Medicine, 163(6), 681-687.

Ezzati, M., Lopez, A. D., Rodgers, A., Vander, H. S., \& Muray, C. J. (2002). Comparative risk assessment collaborating group: Selected major risk factors and global and regional burden of disease. Lancet, 360(9343), 1347-1360.

Ho, H. A., Nguyen, T. M., Vo, T., Derese, A., \& Devroey, D. (2018). Prevalence, awareness, treatment, and control of hypertension and its risk factors in (Central) Vietnam. International Journal of Hypertension, 2018, Article 6326984.

Hội Tim mạch học Việt Nam. (2014). Tài liệu hội thảo Tim mạch toàn quốc năm 2014 [Documents of the National Heart Conference 2014]. Retrieved January 11, 2021, from http://vnha.org.vn/

Lee, H. S., Park, Y. M., Kwon, H. S., Lee, J. H., Park, Y. J., Lim, S. Y.,... Lee, W. C. (2010). Prevalence, awareness, treatment, and control of hypertension among people over 40 years old in a rural area of South Korea: The Chungju Metabolic Disease Cohort (CMC) study. Clinic Expert Hypertens, 32(3), 166-178.

Marshall, I. J., Wolfe, C. D. A., \& McKevitt, C. (2012). Lay perspective on hypertension and drug adherence: Systematic review of qualitative research. Biomedicine Journal, 344(3953), 1-16. 
Meiqari, L., Essink, D., Wright, P., \& Scheele, F. (2019). Prevalence of hypertension in Vietnam: A systematic review and meta-analysis. Asia Pacific Journal of Public Health, 31(2), 101-112.

Puveearasan, K., \& Pankaj, B. (2018). Knowledge and perception of hypertension among hypertensive patients attending rural health and training center, department of community medicine, SRMC \& RI. International Journal of Community Medicine and Public Health, 5(6), 2323-2326.

Rahman, A. R. A., Ji-Guang, W., Gary, M. Y. K., Dante, D. M., Piyamitr, S., \& Renan, S. (2015). Perception of hypertension management by patients and doctors in Asia: Potential to improve blood pressure control. Asia Pacific Family Medicine, 14(2), 1-11.

Rahman, S., Hu, H., McNeely, E., Rahman, S. M., Krieger, N., Waterman, P.,... Gragg, R. D. (2008). Social and environmental risk factors for hypertension in African Americans. Florida Public Health Review, 5(1), 64-72.

Rampal, L., Rampal, S., Azhar, M. Z., \& Rahman, A. R. (2008). Prevalence, awareness, treatment and control of hypertension in Malaysia: A national study of 16,440 subjects. Public Health, 122(1), 11-18.

Taylor, C., \& Ward, A. (2003). Patients' views of high blood pressure, its treatments and risks. Australian Family Physician, 32, 278-282.

Tổng cục Thống kê. (2012). Kết quả điều tra biến động dân số và nhà ở năm 2012 [Results of the 2012 population and housing change survey]. Retrieved January 12, 2021, from https://www.gso.gov.vn/

Trung tâm Nghiên cứu Chính sách và Phòng chống Chấn thương. (2016). Thực trạng tăng huyết áp ở Việt Nam [Situation of hypertension in Vietnam]. Retrieved November 30, 2020, from http://cippr.huph.edu.vn/vi/node/98

Wakayabashi, M. (2013) Socio-economic factors influencing the prevalence of hypertension in the rural elderly population of Thai Binh Province, Northern Vietnam, International Journal of Collaborative Research on Internal Medicine and Public Health, 5(7), 532-544.

Whelton, P. K., He, J., \& Muntner, P. (2004). Prevalence, awareness, treatment and control of hypertension in North America, North Africa and Asia. Journal Human Hypertension, 18(8), 545-551.

World Health Organization (WHO). (2011). Aging and global health. Bethesda, MD: NIH Publication.

Wu, Y., Tai, E. S., Heng, D., Tan, C. E., Low, L. P., \& Lee, J. (2009). Risk factors associated with hypertension awareness, treatment, and control in a multi-ethnic Asian population. Journal of Hypertension, 27(1), 190-197. 